\title{
Available Benthic Energy Coefficient (ABEC): a generic tool to estimate the food profitability in coastal fish nurseries
}

\author{
A. Tableau ${ }^{1,2, *}$, H. Le Bris ${ }^{1}$, A. Brind'Amour ${ }^{2}$ \\ ${ }^{1}$ Agrocampus Ouest, UMR 985 Ecologie et Santé des Écosystèmes, 65 rue de Saint Brieuc, CS 84215, 35042 Rennes Cedex, France \\ ${ }^{2}$ Département Ecologie et Modèles pour l'Halieutique, IFREMER, rue de l'Île d'Yeu, BP 21105, 44311 Nantes Cedex 03, France
}

\begin{abstract}
The benthic production of prey seems to be one of the main drivers among many environmental factors that influence the quality of fish nurseries and potentially limit their carrying capacity. However, the contribution of food availability in the growth and survival of juveniles is still controversial. The Available Benthic Energy Coefficient (ABEC) aims to assess the trophic profitability of benthic invertebrate prey; this concept reflects the combination of energy richness and availability of prey. A value of the coefficient was associated with each prey species. This value was calculated from the product of 4 components: (1) mass energy, (2) productivity, (3) regeneration, and (4) accessibility. Thus, this coefficient is expressed as a quantity of energy per unit of weight and per year. From this coefficient, it is simple to calculate the annual production of profitable energy for the fish community in a delimited nursery; it only needs information about the biomass of benthic invertebrates via a standard sampling method. This tool appears to be decisive in properly estimating the carrying capacity of such a fish nursery. Prey classifications based on taxonomy or trophic guilds are widely used in predator-prey studies; comparison with a classification based on ABEC highlighted the energetic heterogeneity of these groups. ABEC can also be used as an index of profitable energy, thereby substituting the usual classifications of prey in trophic studies.
\end{abstract}

KEY WORDS: Predator-prey relationship $\cdot$ Secondary production $\cdot$ Prey availability $\cdot$ Demersal fish $\cdot$ Nursery habitat $\cdot$ Carrying capacity $\cdot$ Bioenergetics

\section{INTRODUCTION}

Coastal habitats are used as nurseries by many species and are thus considered essential for achieving the life cycle of several demersal and benthic fishes (e.g. Solea solea or Pleuronectes platessa) (Peterson et al. 2000, Beck et al. 2001, Fulford et al. 2011). Among the many environmental factors (e.g. depth, sediment, predation, food availability) that influence the quality of a nursery habitat and thus potentially limit its carrying capacity, the production of potential prey in the benthos seems to be one of the main drivers (Gibson 1994, Wouters \& Cabral 2009). However, the relative contribution of food availability to the growth and survival of juveniles is still widely discussed (Le Pape \& Bonhommeau 2013). Some authors suggest that predation pressure from the fish community has no (or relatively little) impact on the biomass of benthic fauna (e.g. Gee et al. 1985, Shaw \& Jenkins 1992). Thus, food availability would not be a limiting factor for the juveniles in these nursery habitats (Ross 2003, Hampel et al. 2005, Vinagre \& Cabral 2008). However, other authors posit that fish communities regulate the distribution of benthic fauna in estuarine and coastal ecosystems. Food availability in such habitats would thus be a limiting factor (Nash \& Geffen 2000, Craig et al. 2007, Nash et al. 2007). 
Studies that arrive at these contradictory conclusions use different methodologies; some are based on analysis of negative density-dependent growth, which reflects competition for food (e.g. van der Veer \& Witte 1993, Craig et al. 2007); others directly test the hypothesis that the quantity of available food determines the carrying capacity (hereafter called the 'trophic carrying capacity') by comparing fish demand for food with the food supply (e.g. Collie 1987, Vinagre \& Cabral 2008). To test this hypothesis, we suggest that an energetic approach, developed at the fish community scale (unlike the previously cited studies), would provide a suitable framework to estimate the trophic carrying capacity of nurseries and thus determine the relative importance of food availability in these habitats. Prior to any assessment of the trophic carrying capacity, it seems essential to energetically quantify the food available to the fish community. Food availability can be estimated using generic tools that should consider life history traits of benthic invertebrates to relevantly quantify the benthic energetic supply available to fish species.

Most predator-prey studies describe benthic prey as a simple quantity of dry mass or gross energy (Collie 1985, Pihl 1985, Vinagre \& Cabral 2008). However, according to optimal foraging theory (Emlen 1966, MacArthur \& Pianka 1966), a predator must be 'energetically' penalised to account for the energy it invests to obtain its prey. The term 'profitability' was first introduced by Charnov (1976) to describe this concept of energetic gain in combination with the energy demand of foraging. It is now commonly used in experimental and modelling studies through the $\mathrm{E} / \mathrm{T}$ ratio (energy benefit/searching and handling time) (e.g. Werner et al. 1983, Lai et al. 2011, Visser \& Fiksen 2013). However, the time investment of a predator is not directly observable given the technical constraints of large-scale in situ surveys. Following optimal foraging theory, a predator tends to maximise this ratio; thus, the variation in predation rates among prey species is expected to reflect this E/T ratio, i.e. the predators' interest in the prey species studied. Assuming that biological and behavioural features of benthic invertebrates (e.g. burrowing, diving) make them more or less accessible to fish, and thus available and interesting as potential prey, it is possible to relate the variation in predation rate to these features. A coefficient of 'interest' is therefore associated with these features. Consequently, the gross energy provided by prey can be weighted by this penalising component within an energetic tool to properly reflect the prey's level of interest (to the fish) as a food source.
This study aimed to develop the 'Available Benthic Energy Coefficient' (ABEC), a generic energetic tool in which the profitability of prey is defined as a combination of its energy supply (i.e. energetic gain) and its accessibility to predators (i.e. energetic penalty). We developed and applied ABEC using data from a coastal case study, the Bay of Vilaine located in the northern Bay of Biscay, France. The development of ABEC raised 3 main issues which are thoroughly assessed in this study: (1) finding a method to calculate the annual estimated energy of prey using a '1-time' observation of biomass from scientific surveys, (2) defining relevant criteria (generic and consistent with empirically known predator-prey relationships) for assigning any benthic prey species to an accessibility class, and (3) developing and fitting coefficients for each accessibility class. These coefficients are key components of ABEC, as they weight the energy supplied by prey to a predator.

\section{MATERIALS AND METHODS}

\section{Study site}

The Bay of Vilaine (Fig. 1) is one of the most productive nursery grounds in the Bay of Biscay (Le Pape et al. 2003). It has been studied for more than $30 \mathrm{yr}$, producing valuable knowledge about its fish (Nicolas et al. 2007, Kopp et al. 2013) and benthic invertebrate (Le Bris \& Glemarec 1995, Brind'Amour et al. 2009, 2014) communities. Given such data and a knowledge-rich context, the bay constitutes a relevant framework for developing a tool for benthic invertebrate prey energetics. The study area covers the subtidal grounds located from 5 to $30 \mathrm{~m}$ in depth. It is mostly covered by sediments with high proportions of fine particles (diameter $<63 \mu \mathrm{m}$ ), between 40 and $80 \%$ for sandy muds and above $80 \%$ for muds (Le Bris \& Glemarec 1995).

\section{Sampling protocol}

Benthic invertebrate sampling

Benthic macrofauna of the Bay of Vilaine were sampled using a van Veen grab (van Veen 1933) during the late summer (September) of 2008 (Fig. 1). Once aboard, grab samples were immediately rinsed with a $1 \mathrm{~mm}$ mesh on the boat deck and then collected in zipper bags and fixed with formalin to a final concentration of $7 \%$. In the labora- 


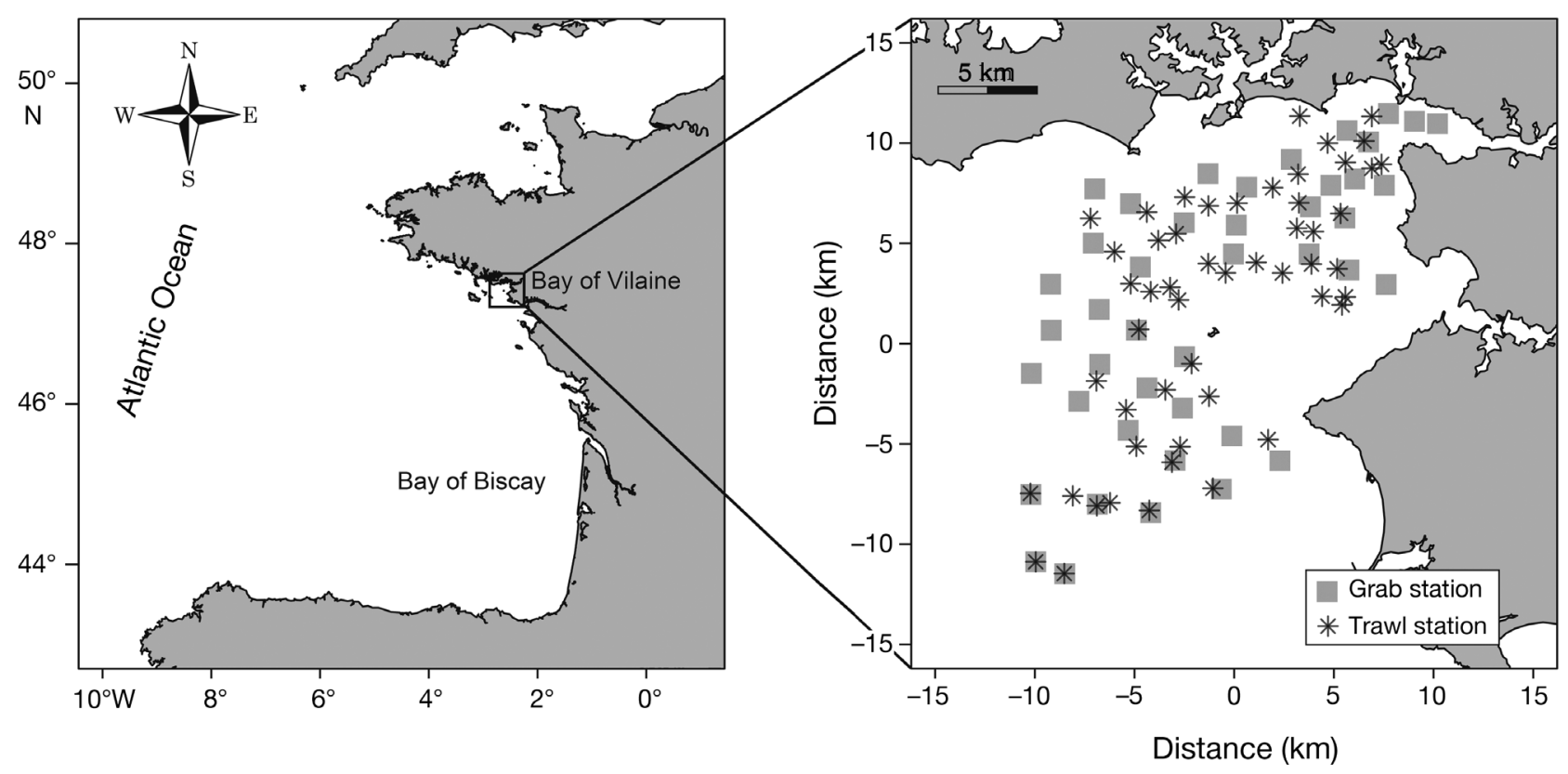

Fig. 1. Location of the Bay of Vilaine in the Bay of Biscay, France, and sampling stations (trawls and grabs). Symbols indicate mean coordinates of each haul

tory, samples were rinsed with water and then fractionated using a column of 5 successive sieves of different mesh sizes (from 16 to $1 \mathrm{~mm}$ square mesh). The benthic invertebrates from each mesh size were stored in a $70 \%$ ethanol solution and identified to species level whenever possible, or to higher taxa, then weighed. A total of 160 taxa were identified. The 3 replicates performed in each of the 42 sampling stations were pooled, and density of benthic invertebrate fauna was estimated given a grab-sampled area of $0.1 \mathrm{~m}^{2}$ (Gallardo 1965, Eleftheriou \& McIntyre 2005).

\section{Gut content data}

Along with the grab sampling, the Bay of Vilaine was also sampled using a $2.9 \mathrm{~m}$ wide and $0.5 \mathrm{~m}$ high beam trawl, with a $20 \mathrm{~mm}$ stretched mesh net in the cod end. Each haul was performed at stations displaying homogeneous sediment and water depth and lasted $15 \mathrm{~min}$, covering a surface area between 4500 and $5000 \mathrm{~m}^{2}$. A total of 52 hauls were conducted. Each haul was weighed, and fish were identified, counted and weighed by species. We selected the 5 most numerically dominant species within the fish community and kept them for gut content analyses: 4 flatfish species (Buglossidium luteum, Dicologlossa cuneata, Pleuronectes platessa, Solea solea) and 1 demersal species (Trisopterus luscus). These spe- cies are representative of the fish community that feeds on benthic macroinvertebrates (they correspond to $80 \%$ of the total biomass of this community). A total of 426 guts sampled from 18 stations were removed and fixed with formalin at $10 \%$, then rinsed with water for ultimate dissection. All benthic invertebrates from stomachs and intestines were stored in a $70 \%$ ethanol solution to be identified to species level whenever possible, or to higher taxa. A total of 114 taxa were identified.

Prey from gut contents were partially damaged by the digestion process; thus, the identification resolution was generally lower than that in the grabs. To improve identification of prey in gut contents, we compared prey taxa from the gut to the corresponding grab taxa; for instance, if arms of the genus Ophiura (Echinodermata) were observed in gut contents and the species Ophiura ophiura was found only in the associated grabs, the genus was identified to the $O$. ophiura species. When no prey from the grab closely matched those from the gut, nothing was changed, and the prey was identified at the lowest level possible. These modifications corresponded to $3 \%$ of the total abundance of prey.

\section{Selection of potential prey}

A taxon was considered as potential prey if its relative abundance and occurrence reached an arbi- 
trary threshold of $1 \%$ in the gut contents of at least 1 fish species. For taxa poorly identified in the gut contents, e.g. Abra spp., we kept all of the related species (Abra abra, A. nidita) found in grabs, as those species represented more than 1/1000 of the total biomass or $0.5 / 1000$ of the total abundance. This step allowed a large set of potential prey to be retained. Species found mainly in the $16 \mathrm{~mm}$ sieve of the grab sample were rejected, as they were larger than the mouth sizes of the fishes studied (Wainwright \& Richard 1995). Thus, 95 taxa were considered as potential prey of the 5 fish species. These prey represented 98.9 and $95.7 \%$ of the in situ abundance and biomass, respectively, of the benthic fauna.

\section{Composition of ABEC}

ABEC aims to estimate the energetic value of benthic invertebrate prey which is profitable for an assemblage of predators. A value is thus associated with each prey species. The assemblage of predators considered are fish commonly found in the benthodemersal community. The ABEC value is calculated from the product of 4 components: (1) mass energy $(E)_{i}(2)$ productivity $(\pi)$, defined as the annual production divided by the annual mean biomass and which is a measure of a species' biomass turnover rate (Dolbeth et al. 2012); (3) a coefficient of regeneration $(R)$; and (4) a coefficient of accessibility $(A)$ :

$$
\mathrm{ABEC}_{i}=E_{i} \times \pi_{i} \times R_{i} \times A_{i}
$$

where $E$ is expressed in $\mathrm{kJ} \mathrm{g}^{-1}, \pi$ is expressed in $\mathrm{yr}^{-1}$, and $R$ and $A$ are unitless. Thus, the coefficient corresponds to a quantity of energy per unit of wet mass and per year for prey species $i$.

\section{Mass energy coefficient $(E)$}

Conversion of the wet mass of benthic invertebrates to gross energy quantities was accomplished using a coefficient of ash-free dry mass divided by the wet mass (AFDM/WM) and an energy conversion factor (energy/AFDM) in $\mathrm{kJ} \mathrm{g}^{-1}$, taken from a database developed by Brey et al. (2010). Individual energy quantities were estimated from the product of both coefficients and individual biomasses. Whenever a conversion factor for a studied species was not available or was based on a single data point, we used the conversion factor of the closest taxon (e.g. Ampelisca for Ampelisca spinipes).
Productivity $(\pi)$

We retrieved 300 productivity values from 64 published articles or theses (available from the corresponding author). $\pi$ ratios from the literature were used only for taxa identified at the species level. Given the variability in $\pi$ values for a single species, we used mean $\pi$ whenever at least 5 values were available from sites with environmental conditions (temperature and depth) similar to the studied site. The empirical productivity model built by Brey (2012) was used for the remaining taxa. Table 1 displays the input data required to calculate productivity values. Mean body energy was calculated from the product of mean body wet mass of each taxon and the associated mass energy (Brey et al. 2010). The mean bottom temperature used was computed from the MARS 3D model (Huret et al. 2013) using data from the Bay of Vilaine. The mean temperature in 2008 was $13.9^{\circ} \mathrm{C}$ at the bottom and varied in the studied area from 13.3 to $14.5^{\circ} \mathrm{C}$. Depth was recorded during the scientific survey. Mobility and feeding parameters were assessed using different sources: WoRMS (WoRMS Editorial Board 2013), MarLIN (MarLIN 2006), and Lincoln (1979). Reliable productivity ratios were obtained from the literature for 6 of the 95 selected taxa. The Brey (2012) model was used for the remaining 89 taxa.

\section{Coefficient of regeneration $(R)$}

Productivity data gathered from the literature did not consider the regeneration process of benthic species. However, according to de Vlas (1985), production associated with somatic regeneration can be as high as the classical growth production; this was

Table 1. Data required in the Brey model (2012) to provide benthic invertebrate productivity ratios $(\pi)$ of these taxa (89 of 95 selected taxa) for which suitable $\pi$ values were not available from the literature

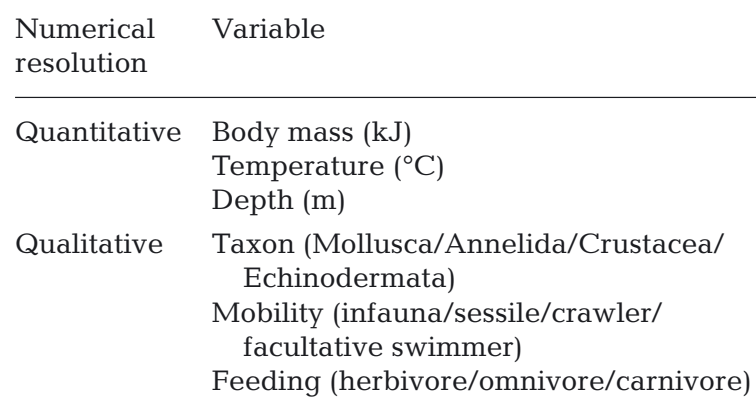


observed notably for the bivalve Macoma balthica and the polychaete Arenicola marina. Based on Clavier (1984), Brey (2001), Sköld et al. (1994), and Bourgoin \& Guillou (1994), regeneration due to fish cropping on the polychaete Euclymene oerstedi and the echinoderms Amphiura filiformis and Acrocnida brachiata was estimated at 20,15 , and $18 \%$, respectively, of the annual production. Bowmer \& Keegan (1983) reported that Amphiura filiformis bodies regenerated at an average of $25 \%$, a value which was roughly consistent with previous results and confirms the phenomenon for this species.

Given the dearth of information in the literature regarding regeneration rates, we extrapolated the available data on species for which we knew cropping by fish occurred but for which no data were available (half the species in the sample). This was done by following the precautionary principle. In concrete terms, the production of polychaetes and echinoderms with long arms was raised by 20 and $15 \%$, respectively (i.e. the minimum value in the literature). Since only 1 value was available for bivalve species with a developed siphon, we arbitrarily assumed half of this value, i.e. $50 \%$. In all cases, these values were most likely underestimated (de Vlas 1985). A coefficient for regeneration was calculated by adding 1 to the regeneration rate (i.e. $R=1+$ regeneration rate). The product of this coefficient and the productivity equalled effective productivity. For instance, for Amphiura filiformis, given that $\pi=$ 0.73 and the regeneration rate $=15 \%$, effective productivity $=\pi \times R=0.73 \times(1+0.15)=0.84$.

\section{Coefficient of accessibility of prey $(A)$}

The combination of the first 3 components along with the biomass provides the gross energy annually produced by a community of prey. However, as mentioned in the 'Introduction', the catch rate of prey varies among prey species, based on their accessibility to predators. The term 'accessibility' is related here to predator and prey abilities and behaviours (i.e. capture and avoidance). We hypothesise that accessibility reflects the availability of prey. We thus associated an accessibility level with each prey species and then computed a coefficient for each accessibility level which reflected predator investment. In practice, this was achieved by (1) defining 2 categories of prey accessibility and associating all prey species with one or the other, (2) computing predation rates by comparing the in situ composition of benthic invertebrates (i.e. grab samples) with that observed in the guts of the studied fish species, and (3) modelling the predation rate as a function of accessibility. The accessibility coefficients fitted from the model were then standardised for use as the accessibility component of ABEC (i.e. A).

Accessibility categories. Benthic prey species were categorised into 2 groups of accessibility (hardly or easily accessible), according their ability to avoid bentho-demersal predators. The grouping criteria were based on either location within the sediment or morphological and behavioural features. Species found above or just beneath the sediment surface were considered 'easily accessible': Bivalvia species with a short siphon (e.g. Cerastoderma edule), surface-living Crustacea (e.g. Diastylis bradyi), Echinodermata (e.g. O. ophiura), and Gastropoda (e.g. Philine aperta). Species buried more deeply were considered 'hardly accessible': Bivalvia species with a developed siphon (e.g. Abra alba), subsurface-living Echinodermata (e.g. Amphiura filiformis), Gastropoda (e.g. Turitella communis), and sedentary Polychaeta (e.g. Lagis koreni). Species with the ability to quickly shelter in the sediment were also considered 'hardly accessible': tube-dwelling crustaceans (e.g. Haploops nirae) and errant polychaetes (e.g. Nephtys sp.) that have the ability to escape because of their burying capacity.

Computation of accessibility coefficients. For each prey species found in the stomach contents of a predator (i.e. fish), the predation rate was computed in 2 steps. (1) The abundance of an invertebrate species caught by the studied fish species (representative of the fish community) was estimated for each sampling station as follows:

$$
\begin{aligned}
& \text { prey total abundance }= \\
& \sum_{j \in N \text { fishspecies }} \overline{\text { prey }_{j}} \times \text { fish }
\end{aligned}
$$

where $\overline{\text { prey }}_{j}$ is the mean number of a prey species, computed from the gut contents of all fish individuals of a species $j$ captured in a sampling station, and $f i s h_{j}$ is the abundance of the fish species $j$ observed at the same sampling station. Therefore, prey total abundance is the sum of all prey caught by the studied fish species at each sampling station. (2) We computed the predation rate as the ratio of the total abundance of prey over the density of prey found in the grab samples (i.e. the in situ density of prey):

$$
\text { predation rate }=\frac{\text { prey total abundance }}{\text { in situ grab prey density }}
$$

The predation rate as defined here assumes that each predator can potentially eat all of the prey. Each 
grab was associated with adjacent sampling stations if it was located within a $3 \mathrm{~km}$ radius, the maximum area potentially prospected daily by a juvenile, given their swimming ability (Gibson et al. 1998, Burrows et al. 2004, Vinagre et al. 2006).

Using the following generalised linear model, we tested the hypothesis that the accessibility level of prey has an effect on the predation rate and quantified the coefficients related to each accessibility class. We used the Gaussian family and $\log _{10}$ link function; the intercept term was removed because the aim was to assess the effect of each accessibility level and not to assess how these accessibility levels are distributed around the mean predation rate:

$$
\log _{10}(\text { predation rate }) \sim \text { accessibility }
$$

As previously mentioned, prey accessibility was defined in 2 categories (hardly or easily accessible). The model was deemed relevant if (1) the accessibility variable had a significant effect (as tested with an ANOVA) and (2) its estimates were consistent with the assumption that 'hardly accessible' prey had a lower predation rate than 'easily accessible' prey. As the model was developed using $\log _{10}$-transformed data, both predictions of predation rate, which directly corresponded to both estimates of the accessibility categories, were exponentially transformed using the correction of Laurent to obtain unbiased predicted values (Laurent 1963). The normality assumption was tested using the Wilks-Shapiro test.

We standardised both estimates by dividing them by the highest estimate of the 2 accessibility categories, i.e. the 'easily accessible' category. This standardisation provided generic coefficients of accessibility. Therefore, the ABEC accessibility coefficient of a prey species corresponded to the standardised estimate of the accessibility category $k$ to which it belonged:

$$
A_{k}=\frac{\text { accessibility estimate }_{k}}{\text { 'easily accessible estimate' }}
$$

Variability in ABEC composition within the prey community

To represent and identify patterns of variation in ABEC components between prey taxa, Principal Component Analysis (PCA) was performed in the $\mathrm{R}$ environment (R Development Core Team 2012) using the package FactoMineR (Lê et al. 2008). Values of each component and ABEC were detailed for the 7 most abundant species.

\section{Comparison of prey classifications}

Groups of benthic prey are commonly used as explanatory biotic variables in habitat models or in the description of predator-prey relationships (Nicolas et al. 2007, Brind'Amour et al. 2009, Kopp et al. 2013). These groups, most often based on taxonomic classification or trophic guilds, are useful, as they reduce the number of variables to include in a model. However, they often have little relevance in terms of energetic gain. In this study, we proposed a substitute to the usual classifications (i.e. trophic guilds and taxonomy) of benthic prey. This new energetic classification used ABEC as an index to define groups of prey based on the energy they may provide. It was calculated as follows. Once ABEC was calculated for the 95 prey taxa, hierarchical ascendant classification of these prey species was performed using the Euclidean distance with the Ward classification algorithm (Ward 1963). The classification algorithm is simple: each species starts in its own group (95 groups initially), and pairs of groups are merged iteratively following a similarity criterion (Euclidian distance). The best partition was identified using the inertiabased criterion of the Hierarchical Clustering on Principal Components (HCPC) function developed in the R package FactoMineR (Lê et al. 2008). The partition displaying the lowest value was used to assess the best number of groups corresponding to the most compact ABEC values. Concurrently, species were attributed to categories following their taxonomy and trophic guilds (WoRMS Editorial Board 2013). Comparison between the 3 classifications (ABEC, trophic guilds, and taxonomy) was done using boxplots and by computing Mantel correlations (Mantel 1967) on classifications matrixtransformed with the Jaccard similarity coefficient (Jaccard 1901).

\section{Application of ABEC in the Bay of Vilaine nursery ground}

Scientific surveys in the Bay of Vilaine were conducted in March and September 2008, corresponding to the beginning and end, respectively, of the main period of macrobenthic production at this latitude. This peak in production is mainly due to the increase in temperature during summer and is associated with an increase of biomass (e.g. Lagis koreni [Nicolaidou 1983, Elkaim \& Irlinger 1987]; Ampelisca brevicornis [Klein et al. 1975]; Hediste 
diversicolor [Gillet \& Torresani 2003]; Abra alba [Hily \& Le Bris 1984]; C. edule [de Montaudouin \& Bachelet 1996]). Thus, the biomasses recorded during these periods were considered as minima $\left(B_{\min }\right)$ and maxima $\left(B_{\max }\right)$ for most prey species. $\pi$ ratios, and consequently ABEC, need to be applied to values of annual mean biomass $\left(\bar{B}_{\text {in situ }}\right)$ to provide a value of production. Therefore, we estimated $\bar{B}_{\text {in situ }}$ as the mean biomass between the 2 sampling periods. As $B_{\min }$ were missing for several species, but $B_{\max }$ were recorded for all of the species, we estimated $\bar{B}$ using a simple linear regression between $\bar{B}_{\text {in situ }}$ and $B_{\max }$ for the species for which we had all of the data, and we used the coefficient of regression $(\alpha)$ to predict $\bar{B}_{\text {pred }}$ for all of the benthic species.

$$
\bar{B}_{\text {pred }}=\alpha \times B_{\max }
$$

ABEC was calculated for all of the prey species sampled in the Bay of Vilaine. Values of the coefficient are expressed in $\mathrm{kJ} \mathrm{g}^{-1} \mathrm{yr}^{-1}$. The product of ABEC along with the predicted annual mean biomass of prey (a wet mass expressed in g) provided an estimate of the production (in $\mathrm{kJ} \mathrm{yr}^{-1}$ ) available for the fish community. The production assessment is thus based on 2 assumptions: (1) The production peak and consequently the dynamic of the biomass and density are synchronized among species; this assumption is coherent with the literature observing a peak of production in summer (cf. references above). (2) The body mass dynamic is also similar among species and allows us to get productivity values from Brey's model. This latter assumption is supported by the adequacy between outputs of Brey's model and productivity ratios collected in the review (cf. 'Discussion: Reliability of core data').

To illustrate the contribution of each component to the final coefficient (ABEC) and to compare the spatial distributions of profitable production and biomass, we successively added each ABEC component over the annual mean biomass. We tested whether the distribution of the available energy production values (estimated using ABEC) corresponded to the distribution of gross biomass values using analyses accounting for spatial correlation. A linear model between these 2 variables, in which the autocorrelation structure was considered via latitude and longitude, was built using the function 'gls' from the 'nlme' package (Pinheiro et al. 2013). All computations and statistical analyses were done using $\mathrm{R}$ ( $\mathrm{R}$ Development Core Team 2012).

\section{RESULTS}

\section{Fitted accessibility coefficients}

Predation rates were estimated for $60 \%$ of the taxa identified in gut contents. Around $30 \%$ of the remaining taxa are rarely caught by predators; they represent less than $14 \%$ of the abundance of prey items ingested. Though these taxa were observed in the study site, they were absent in the grab stations associated with the trawl stations involved; the distance between grab and trawl samples was sometimes $>1 \mathrm{~km}$, which could explain this lack of information. Only a few taxa (around 10\%) that occurred in gut contents were never sampled in the grab. These taxa were very small benthic invertebrates (meiofauna) or highly mobile suprabenthic invertebrates of the Crangonidae family, representing less than $3 \%$ of the prey items.

Coefficients of accessibility were applied to the 95 prey taxa. The standardised coefficients were 0.11 and 1.00 for the 'hardly accessible' and 'easily accessible' prey categories, respectively (Fig. 2). Differences between the 2 values (ANOVA: p-value $<0.001$ ) clearly underlined the disparity between the 2 prey categories. The accessibility effect explained $20 \%$ of the variation in predation rate.

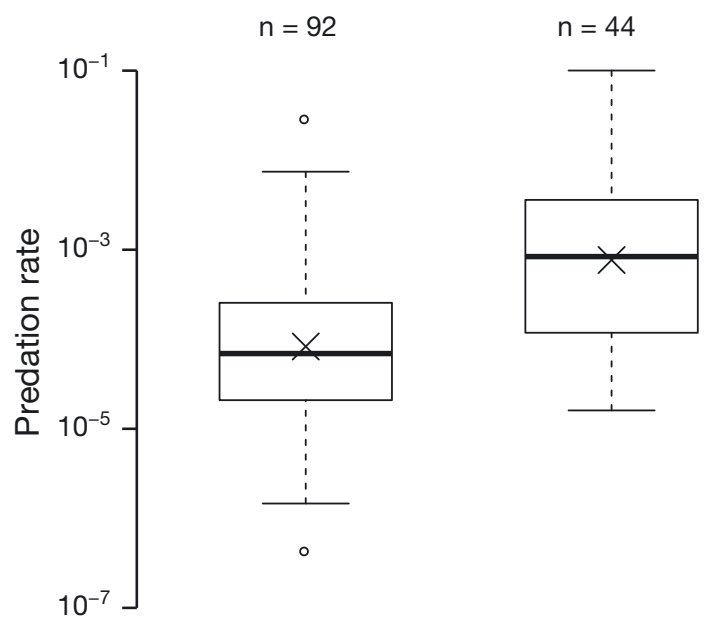

Hardly accessible Easily accessible

Fig. 2. Distribution of $\log _{10}$-transformed predation rates for each accessibility category, displayed as Tukey boxplots; the thick line and the cross indicate median and mean rates, respectively; the bottom and top of the boxes indicate the first and third quartiles, respectively; the ends of the whiskers are the lowest and highest data values within the 1.5 interquartile range of the lower quartile and the upper quartile, respectively; the dots are outliers. Mean rates correspond to the estimates of the model. After standardisation, they are used as accessibility coefficients 


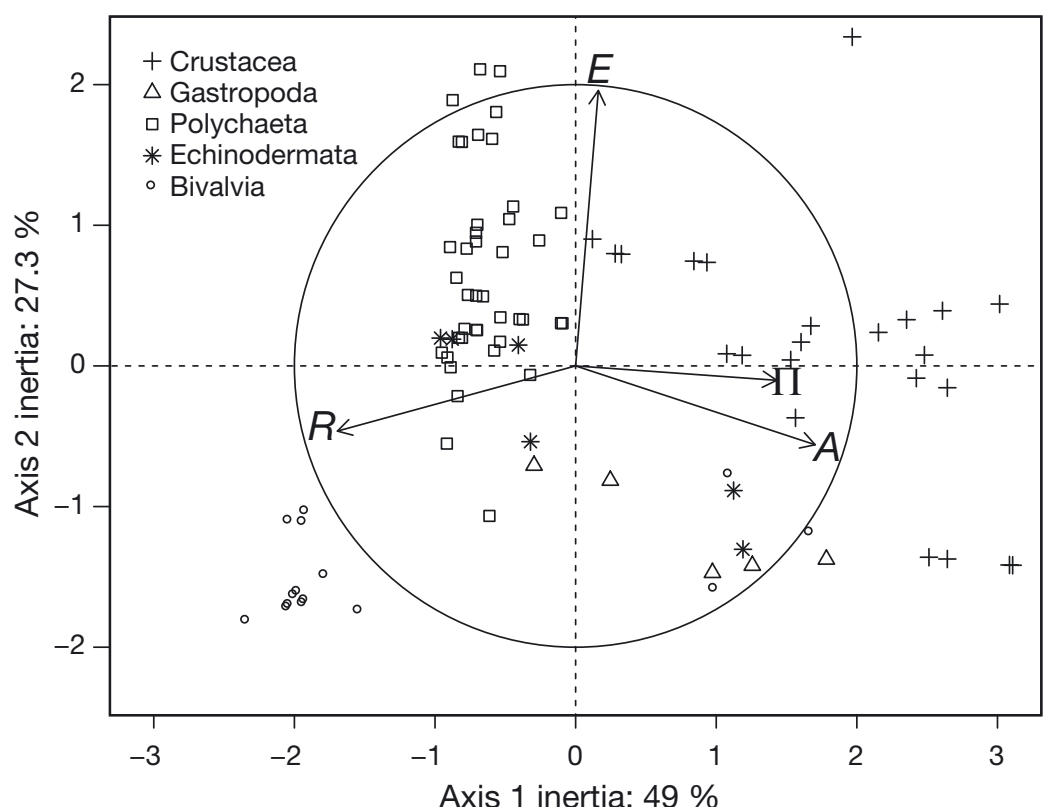

Fig. 3. Principal Component Analysis (PCA) displaying prey taxa projection on the 4 Available Benthic Energy Coefficient (ABEC) components ( $A$ : accessibility $E$ : mass energy, $R$ : regeneration, $\pi$ : productivity). Prey taxa are classified in taxonomic groups. The correlation circle of variables is displayed to help interpret the axes

\section{Diversity of ABEC composition within the prey community of the Bay of Vilaine}

The first 2 axes of the PCA accounted for $76 \%$ of ABEC variance. The 4 variables structuring ABEC represented on the first PCA plane were weakly correlated with each other (Fig. 3). Axis 2 was highly correlated with mass energy $(E)$, whereas axis 1 was associated with the 3 other variables; the regeneration coefficient $(R)$ was negatively correlated with accessibility $(A)$. The positions of prey along axis 2 highlighted that polychaetes contained more energy than echinoderms (Student's $t$-test: $p<0.001$ ) and species with shells (gastropods and bivalves) (for both Student's $t$-tests: $\mathrm{p}<0.001)$. Furthermore, crustaceans had higher productivity and were generally more accessible than the other groups (Student's $t$-test: $\mathrm{p}<0.001)$. Detailed data for the 7 most representative species (Table 2) seemed to indicate that ABEC values were weakly associated with taxonomic groups, except for echinoderms. Thus, combination of the 4 components of ABEC smoothed the previously observed trend. All ABEC values are detailed in the Appendix.

\section{Comparison of prey classifications}

Classification analyses on ABEC values suggested 3 groups of prey (Fig. 4). Group A (ABEC $>3.00 \mathrm{~kJ} \mathrm{~m}^{-2}$ $\mathrm{yr}^{-1}$ ) corresponded to easily accessible prey species with high effective productivity; $\pi \times R=4.9$ vs. 2.0 and 2.7 for groups $\mathrm{B}$ and $\mathrm{C}$, respectively. Group B (ABEC $<0.75 \mathrm{~kJ} \mathrm{~m}^{-2} \mathrm{yr}^{-1}$ ) was characterised by hardly accessible prey species with low mass energy coefficients: $E=2.2 \mathrm{~kJ} \mathrm{~g}^{-1}$, on average, vs. 3.1 and $3.6 \mathrm{~kJ} \mathrm{~g}^{-1}$ for groups $\mathrm{A}$ and $\mathrm{C}$, respectively. Group C (ABEC from 0.75 to $3.00 \mathrm{~kJ} \mathrm{~m}^{-2} \mathrm{yr}^{-1}$ ) included both hardly and easily accessible prey.

Groups of ABEC were weakly correlated with the taxonomic groupings (Mantel $\mathrm{r}=0.28, \mathrm{p}$-value $=$ 0.001 ) and were uncorrelated with the trophic guilds (Mantel $\mathrm{r}=-0.01, \mathrm{p}$-value $=0.76$ ), confirming the trend already observed in Table 2. Furthermore, ABEC calculated by taxonomic groups or trophic guilds (Fig. 5) confirmed the Mantel test results: no differences among trophic guilds and significant differences among taxonomic groups. The latter corresponded mainly to the Crustacea group, which had a mean $A B E C$ value 10 times as high as those of the other groups.

Table 2. Component values of ABEC for the 7 main species of the Bay of Vilaine

\begin{tabular}{|llcccrc|}
\hline Species & $\begin{array}{l}\text { Taxonomic } \\
\text { group }\end{array}$ & $\begin{array}{c}\text { Mass energy E } \\
\left(\mathrm{kJ} \mathrm{g}^{-1}\right)\end{array}$ & $\begin{array}{c}\text { Productivity } \pi \\
\left(\mathrm{yr}^{-1}\right)\end{array}$ & $\begin{array}{c}\text { Regeneration } \\
R\end{array}$ & $\begin{array}{c}\text { Accessibility } \\
A\end{array}$ & $\begin{array}{c}\text { ABEC } \\
\left(\mathrm{kJ} \mathrm{g}^{-1} \mathrm{yr}^{-1}\right)\end{array}$ \\
\hline Haploops nirae & Crustacea & 3.64 & 2.87 & 1.00 & 0.11 & 1.15 \\
Owenia fusiformis & Polychaeta & 5.18 & 1.69 & 1.20 & 0.11 & 1.16 \\
Sternaspis scutata & Polychaeta & 3.13 & 1.60 & 1.20 & 0.11 & 0.66 \\
Acrocnida brachiata & Echinodermata & 2.99 & 0.44 & 1.15 & 0.11 & 0.17 \\
Amphiura filiformis & Echinodermata & 2.99 & 0.73 & 1.15 & 0.11 & 0.28 \\
Cerastoderma edule & Bivalvia & 1.06 & 0.82 & 1.00 & 0.11 & 0.87 \\
Abra alba & Bivalvia & 1.11 & 1.92 & 1.50 & 0.11 \\
\hline
\end{tabular}




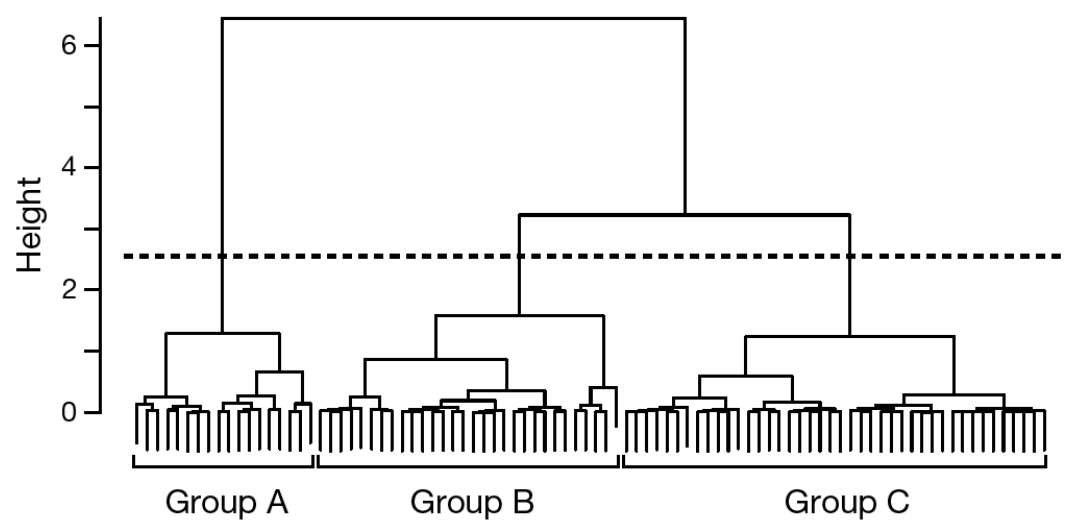

Fig. 4. Hierarchical cluster analysis (Ward algorithm) using the Euclidean distance computed on Available Benthic Energy Coefficient (ABEC)values of the prey. The number of groups was determined using the inertia-based criterion of the Hierarchical Clustering on Principal Components function (Lê et al. 2008)
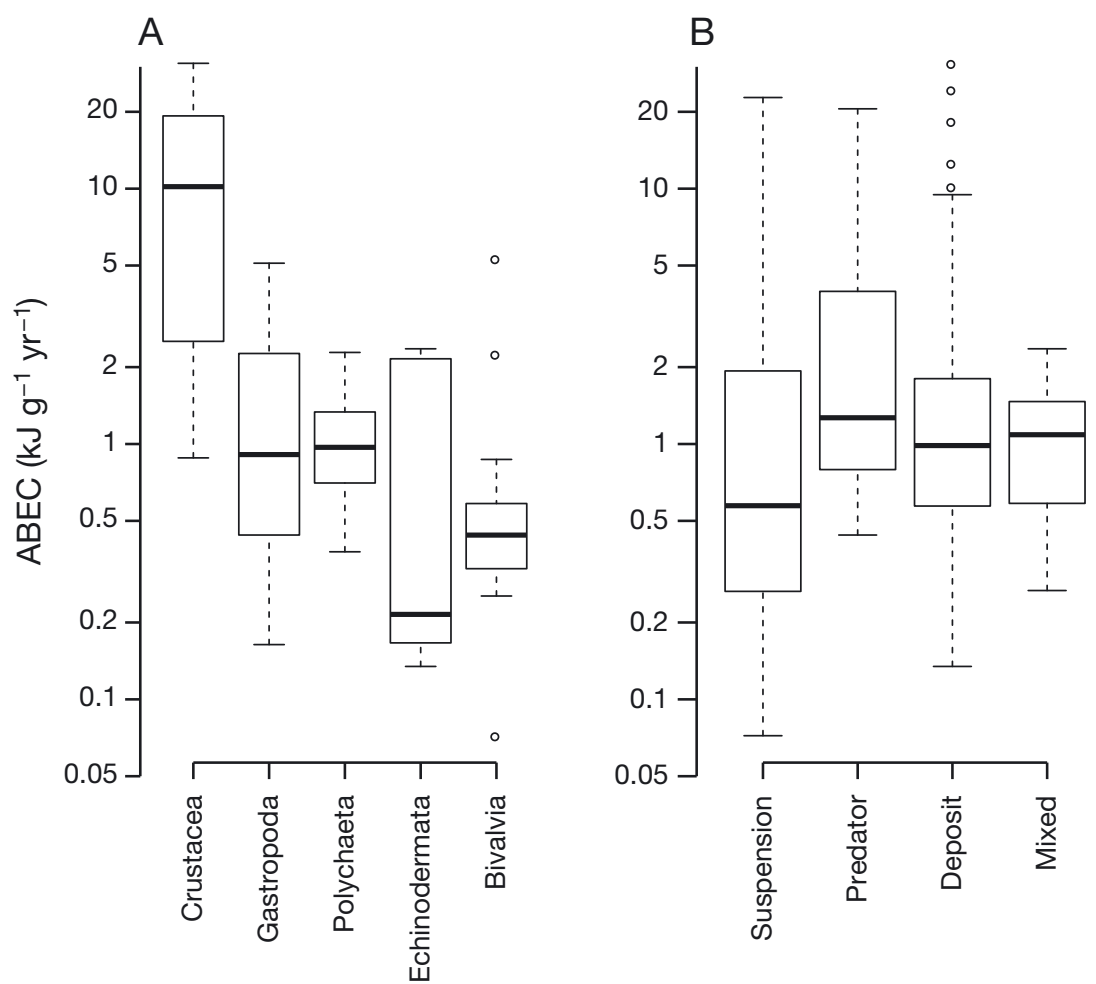

Fig. 5. Available Benthic Energy Coefficient (ABEC) values calculated by (a) taxonomic groups and (b) trophic guilds. Box-plot definitions are given in Fig. 2

\section{Profitability assessment using ABEC in the Bay of Vilaine}

Annual mean biomass was fitted for the 20 species observed in both March and September and present in at least 10 sampling stations. The regression coefficient (i.e. slope) was 0.68 , explaining $96 \%$ of variation.
Fig. 6 presents the steps for calculating the spatial distribution of available energy production for benthodemersal fish predators in the Bay of Vilaine nursery ground in 2008. Fig. 6A corresponds to the predicted annual mean biomass, whereas Fig. 6B-E presents the relative contribution of each component of ABEC to the total profitable energy.

Spatial distribution of the biomass of benthic invertebrates identified 2 areas with high biomass (eastern and southern parts of the bay) and 2 areas with lower biomass (mouth of the estuary and northern part of the bay). Quantitative and qualitative variables based on sediment, organic matter, oxygen, temperature, depth, and salinity were tested. None of these explained the spatial variability observed. Converting the biomass data (Fig. 6A) into energy (Fig. 6B) reduced the relative contribution of the southern part of the bay to the overall energy budget. This was particularly obvious for 5 of the stations which had very low energy (400 $\mathrm{kJ} \mathrm{m}^{-2}$ ) but relatively high biomass $\left(>200 \mathrm{~g} \mathrm{~m}^{-2}\right.$ ). This drop in energy was due to the echinoderm Amphiura filiformis and the bivalve Abra alba, which represented 50 to $90 \%$ of the biomass recorded in these stations. Indeed, echinoderms have a low energy content, and most bivalve mass corresponds to the shell (Brey et al. 2010). Multiplying energy

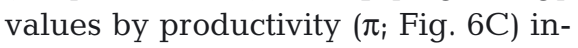
creased the contribution of the western part of the bay, which was composed of the crustacean Haploops nirae (60 to $95 \%$ of the biomass). The contribution of the regeneration coefficient uniformly increased the production (Fig. 6D; Pearson $r=0.99$ with data in Fig. 6C). The accessibility coefficient greatly penalised gross energy production but scarcely modified the patterns described previously (Fig. 6e; Pearson $r=0.99$ with data in Fig. 6D). This illustrates that hardly and easily accessible benthic invertebrates were uniformly distributed in the study area.

Finally, profitable energy production estimated using ABEC (Fig. 6E) was partially correlated with 

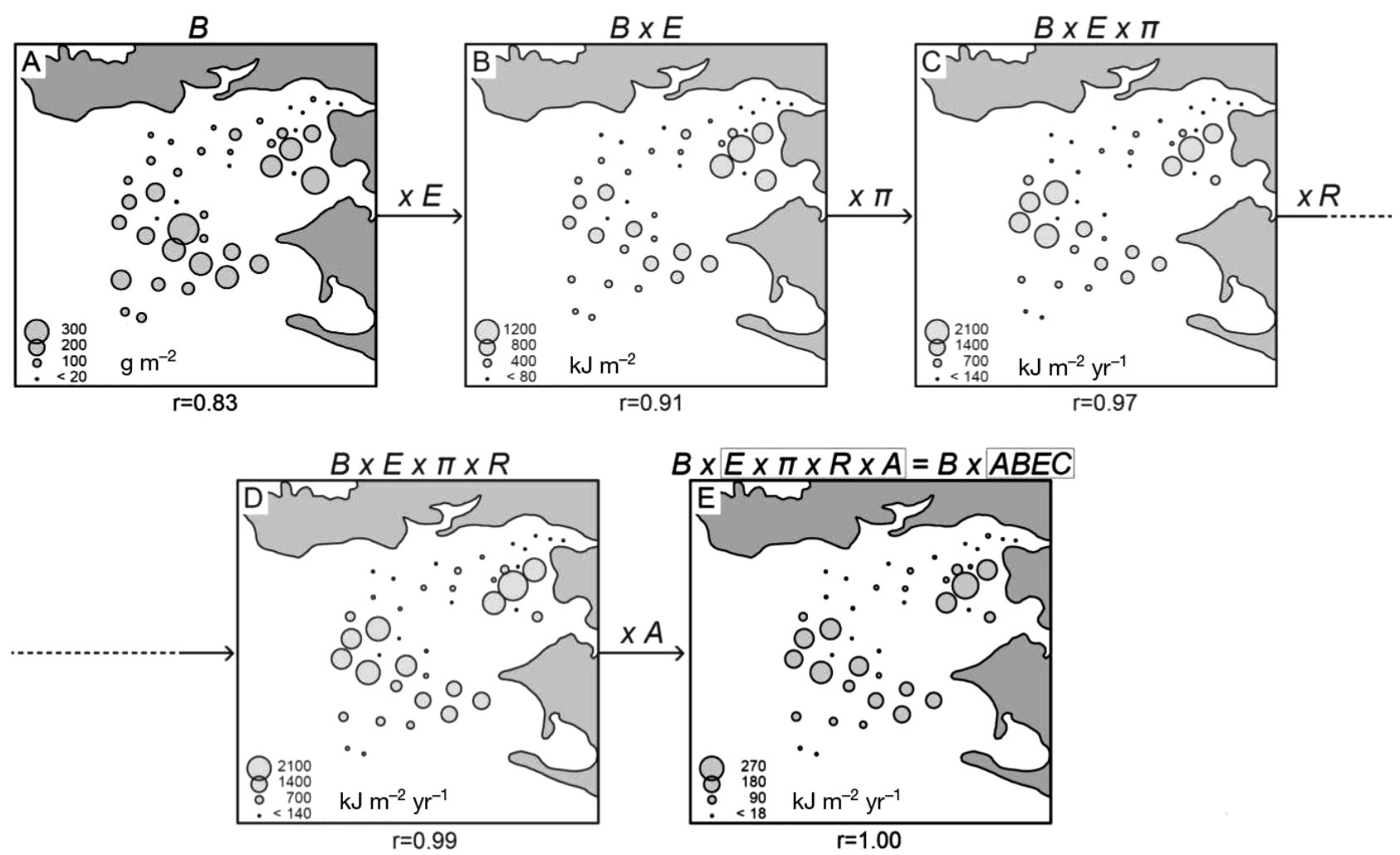

Fig. 6. Spatial distribution of $(A)$ biomass $(B)$ and $(E)$ profitable production $(B \times A B E C) ;(B, C, D)$ components of $A B E C$ are successively included to display their contribution to the spatial variability; Pearson correlation coefficient (r) between (E) profitable production and each other panel is given underneath the panel. A: accessibility, ABEC: Available Benthic Energy Coefficient, E: mass energy, $R$ : regeneration, $\pi$ : productivity

biomass (Pearson $r=0.83$ ). Moreover, ABEC provided a more contrasting distribution of available food than using biomass alone. Production maxima (Fig. 6E) were located on muds at depths of 15 to $25 \mathrm{~m}$ and sandy muds at depths of 5 to $10 \mathrm{~m}$. These 2 areas were mainly dominated by Haploops niraeOwenia fusiformis-Abra alba and Owenia fusiformisAcrocnida brachiata, respectively.

\section{DISCUSSION}

The combination of 3 energy-related components, weighted by the accessibility of prey, provides an energetic coefficient that can be computed for any type of marine benthic prey. This coefficient, called ABEC, converts the gross biomass of benthic invertebrates into an annual production of profitable energy. To the best of our knowledge, it is the first integrated coefficient to be developed that assesses the profitability of benthic prey that benefit the fish community. Although other tools can assess food prefer- ence or prey accessibility (e.g. Ivlev 1961, Strauss 1982, Walters et al. 1997), these aspects are not included in the trophic studies that compare food availability and demand (e.g. Collie 1987, Vinagre \& Cabral 2008). ABEC is a relevant tool for estimating the carrying capacity of similar nurseries because of 2 features: time integration, by considering annual production instead of a temporal snapshot of biomasses, and the weighting of energy supply. The secondary production computed provides insights about e.g. recruitment, mortality, size, cohort structure, and growth type. Therefore, when compared to biomass, ABEC is a major step towards the assessment of the spatial distribution of benthic production. Before extending the use of $\mathrm{ABEC}$ to other ecosystems to assess the carrying capacity, it seems relevant to validate the calibration of the accessibility component. However, because that component is associated with the whole fish community and is independent of the predator density (the component is standardized), it is expected to be resilient among various ecosystems and potentially usable as is. 


\section{ABEC: a theoretically sound and integrated coefficient}

The optimal foraging theory, developed by Emlen (1966) and MacArthur \& Pianka (1966), states that the foraging behaviour of a predator is driven by the maximisation of energy intake per time unit. More specifically, it stipulates that a predator that attempts to maximise energy intake $(E)$ is penalised by the handling $(H)$ and searching $(S)$ time of its prey $[E /(H$ $+S)$ ]. This non-random behaviour of a predator can be interpreted as a preference for certain prey (Shorygin 1931, Hoar et al. 1979, Floeter \& Temming 2003). The large variation in predation rates observed between the prey species selected in our study corroborates this idea of food preference. However, according to Visser \& Fiksen (2013), the concept of feeding preference remains abstract and is hardly practical in differentiating in situ prey. Griffin et al. (2012) suggested using the accessibility of prey, similar to the vulnerability concept of prey (Walters et al. 1997, Ahrens et al. 2012), to explain variations in predation intensity. We posit that the coefficient of accessibility developed in this study theoretically reflects the 'searching time' of the optimal foraging formula. Specific prey characteristics, such as mobility and position within the sediment, could easily be associated with this accessibility concept. In a study conducted in the southern North Sea, Hinz et al. (2005) made an initial attempt to relate prey characteristics (position, mobility, and palatability) and variation in abundance to the diet of Limanda limanda. In the present study, we showed that combining 2 prey characteristics (mobility and position) into a unique component, accessibility, explains a large part of variability in predation intensity: the prey most accessible to bentho-demersal fish correspond mainly to epibenthic species, whereas the least accessible ones correspond mainly to species that bury into or live beneath the surface. This concurs with several other studies conducted in similar ecosystems or experiments (e.g. Hall et al. 1990, Posey et al. 2002). Adding complexity to this 'penalising' component would be an interesting perspective. Considering additional accessibility categories is an initial solution; our analyses showed that a third category, associated with an intermediate burying level, seems relevant but was not significant with the data available (results not shown). Another source of predator energy expenditure is handling time; the rigidity of prey bodies could be a reliable proxy (Hinz et al. 2005), but it would need to be combined with the existing burying criteria to provide relevant mixed categories.
The accessibility component used in this study did not modify the dispersion patterns of food in the Bay of Vilaine, as hardly and easily accessible prey are homogeneously distributed in the bay. However, examples occur where the inaccessibility of a highly profitable and abundant prey (e.g. tubicolous species) might strongly decrease the gross energy available for predators. For instance, Haploops nirae, a tubicolous amphipod, represents more than $90 \%$ of the total biomass in the Bay of Concarneau (Rigolet et al. 2014), but this species is rarely accessible to most fish species and is thus absent from most fish diets $(H$. Le Bris unpubl. data). The way our coefficient is designed, profitable energy would be closer to gross energy in areas of sandy sediment, where surface-living fauna, notably some amphipods and cumaceans, are usually abundant (i.e. easily accessible prey), as observed in coastal ecosystems on the Atlantic coast (Hily 1976, Menesguen 1980, Le Bris \& Glémarec 1996).

\section{Reliability of core data}

Much of the information included in ABEC comes from the literature. The lack of relevant productivity data $(\pi)$, one of the main components of ABEC, led us to estimate productivity for most prey in the study using the model developed by Brey (2012). Other studies also using the Brey model compared their results with other empirical models (Cusson \& Bourget 2005, Dolbeth et al. 2005) and concluded that the former model performed best in a variety of circumstances. Although we do not have any productivity values at the scale of the Bay of Vilaine with which to compare, we are fairly confident in our estimates. For instance, productivity estimates for 6 species (Abra alba, Cerastoderma edule, Corophium volutator, Macoma balthica, Mytilus edulis, Nephtys hombergii) and 3 taxa (Ampelisca, Bivalvia, Polychaeta) for which we had a minimum of $5 \pi$ values from different study sites fell within the range of what is commonly found in the literature. Additionally, Brey (2001) states that the error associated with estimating the production of a single species generally remains high but decreases greatly when averaged over multi-species communities, thus making his model well suited for this study.

Regeneration data were available for a few species and were extrapolated to others. This aspect likely generated uncertainties in ABEC values (Appendix). Assessing the range of these uncertainties is unfortunately impossible given the paucity of data. However, failing to include regeneration leads to underestimating benthic production. In our study, 
aggregating these values at the community scale smooths these uncertainties. Furthermore, the regeneration component improves production estimates without modifying the spatial pattern of production (i.e. Pearson $r=0.99$ between Fig. 6C,D).

Prey biomass in the Bay of Vilaine was estimated using a van Veen grab. This device is one of the most common tools for collecting and estimating benthic infauna, with a sampling efficiency estimated at $90 \%$ in subtidal zones (Lie \& Pamatmat 1965). The remaining $10 \%$ mainly concerns highly mobile suprabenthic organisms (e.g. Crangon crangon and Philocheras trispinosus) escaping from the grab and very small organisms (e.g. Ostracoda and Harpacticoida) that are flushed by the grab mechanism. In our study, some of the aforementioned taxa were found in the diet of the fish but were absent from the grab samples. We assume that these missing taxa had only a small impact on the estimated profitable production of the Bay of Vilaine, as they corresponded to only $3 \%$ of the predators' diet.

\section{Implications for trophic ecology studies}

ABEC was used in the Bay of Vilaine to convert biomass data into annual profitable production for each prey taxon. This production was then aggregated to obtain the production of the entire directly usable prey community to calculate the annual quantity of food that is profitable for a set of predators. When compared to the spatial distribution of biomass, ABEC revealed more heterogeneous food patterns. Therefore, biomass may not be the best proxy to estimate food spatial distribution on an annual basis. Nevertheless, discrepancies between biomass and $A B E C$ distributions remained moderate given the high correlation (Pearson $r=0.83$, Fig. 6). Spatial distributions of biomass and profitable production in the Bay of Vilaine suggest that the 2 values are most likely produced by different processes occurring at different temporal scales. Biomasses are observed at a single moment (a temporal snapshot), whereas profitable production, estimated from ABEC, is calculated on a yearly basis and by definition integrates productivity rates. The dynamic dimension of ABEC combined with biomass data provides integrated information about the food supply. Therefore, ABEC is a good candidate for trophic ecology studies, which require work at an annual time scale. We believe that ABEC is especially relevant in benthic studies that investigate anthropogenic impact on benthic communities, such as trawling impacts (Hinz et al. 2009) or hypoxia (Gray et al. 2002). ABEC is also a good candidate to quantify available energetic inputs in bioenergetic studies.

\section{Flexibility and generic nature of tool}

The multi-component structure of ABEC offers a framework that can be easily manipulated and adapted to other sites that have a different community of prey and/or predators. Applying ABEC to another site requires knowing the biomass of the prey community and readjusting the productivity model, as productivity varies with the temperature of the site. However, prey accessibility categories were defined according to widespread morphological or behavioural traits available in the literature, and the associated accessibility coefficients were fitted to predation pressure data measured at the scale of the predator community (i.e. bentho-demersal fish); therefore, they are not specific to a unique fish species. Consequently, ABEC could be used to compare the quantity of food available from different nursery grounds even if benthic invertebrate communities differ. Additionally, given that biomass data are available on a yearly timescale, ABEC could also be used as an indicator of changes in benthic production.

The mean distance between 2 grab stations in our study is nearly $3 \mathrm{~km}$. The high spatial variability of profitable production between some adjacent stations suggests that a finer sampling resolution would have been more appropriate. For instance, sampling on a $1 \mathrm{~km}$ grid would have been suitable given the relative continuity observed. The Bay of Vilaine is characteristic of an open shallow and muddy estuarine area under the influence of freshwater runoff (Gilliers et al. 2006) and is composed of benthic communities commonly found in other estuarine ecosystems (Brind'Amour et al. 2014). Therefore, we believe that the optimal spatial resolution suggested here would also be appropriate for other coastal nurseries. Alternatively, the sampling design in areas with more heterogeneous substrates, such as the continental shelf, would likely require increasing the sampling effort and/or stratifying the sampling protocol to better describe such ecosystems.

\section{Energetic classification of benthic invertebrate prey}

Taxonomic groups were not distinguished by ABEC, except for crustaceans. This can be explained 
by their high productivity and high accessibility for most of them. Conversely, the absence of correlation between ABEC and trophic guilds was somewhat expected. There are no functional reasons that would explain why a filter feeder, feeding mainly on particulate organic matter, would be of higher (or lower) energetic value than a deposit feeder, feeding on microphytobenthos (Grall et al. 2006). We argue that ABEC values accurately reflect profitability of the prey community. Nevertheless, analysing invertebrate communities with ABEC classification in habitat models would provide a trophic variable that contains information about energetic aspects of the prey community.

\section{CONCLUSIONS}

The generic architecture of ABEC, when combined with biomass data, is able to properly quantify the profitable production of prey for fish communities in nurseries. Hopefully, it will help to resolve debates about the influence of the trophic factor on the actual carrying capacity of such essential habitats.

Acknowledgements. The authors thank Lucille Grimaud and Alexandre Mahuas for their technical help in sorting macrobenthos and analysing gut contents, and the crew of the oceanographic vessel 'Gwen Drez' during the RetroB and Nurse scientific surveys of 2008. They also acknowledge the anonymous reviewers for their helpful comments on an earlier version of the manuscript.

\section{LITERATURE CITED}

> Ahrens RNM, Walters CJ, Christensen V (2012) Foraging arena theory. Fish Fish 13:41-59

Beck MW, Heck KL, Able KW, Childers DL and others (2001) The identification, conservation, and management of estuarine and marine nurseries for fish and invertebrates. Bioscience 51:633-641

Bourgoin A, Guillou M (1994) Arm regeneration in two populations of Acrocnida brachiata (Montagu) (Echinodermata: Ophiuroidea) in Douarnenez Bay, (Brittany: France): an ecological significance. J Exp Mar Biol Ecol 184:123-139

> Bowmer T, Keegan BF (1983) Field survey of the occurrence and significance of regeneration in Amphiura filiformis (Echinodermata: Ophiuroidea) from Galway Bay, west coast of Ireland. Mar Biol 74:65-71

Brey T (2001) Population dynamics in benthic invertebrates. A virtual handbook. Version 01.2. www.thomas-brey.de/ science/virtualhandbook

> Brey T (2012) A multi-parameter artificial neural network model to estimate macrobenthic invertebrate productivity and production. Limnol Oceanogr Methods 10: 581-589

> Brey T, Mueller-Wiegmann C, Zittier ZMC, Hagen W (2010)
Body composition in aquatic organisms - a global data bank of relationships between mass, elemental composition and energy content. J Sea Res 64:334-340

Brind'Amour A, Rouyer A, Martin J (2009) Functional gains of including non-commercial epibenthic taxa in coastal beam trawl surveys: a note. Cont Shelf Res 29:1189-1194

> Brind'Amour A, Laffargue P, Morin J, Vaz S, Foveau A, Le Bris H (2014) Morphospecies and taxonomic sufficiency of benthic megafauna in scientific bottom trawl surveys. Cont Shelf Res 72:1-9

Burrows MT, Gibson RN, Robb L, Maclean A (2004) Alongshore dispersal and site fidelity of juvenile plaice from tagging and transplants. J Fish Biol 65:620-634

Charnov EL (1976) Optimal foraging, the marginal value theorem. Theor Popul Biol 9:129-136

Clavier J (1984) Production due to regeneration by Euclymene oerstedi (Claparède) (Polychaeta: Maldanidae) in the maritime basin of the Rance (northern Britanny). J Exp Mar Biol Ecol 75:97-106

$>$ Collie JS (1985) Life history and production of three amphipod species on Georges Bank. Mar Ecol Prog Ser 22: 229-238

Collie JS (1987) Food consumption by yellowtail flounder in relation to production of its benthic prey. Mar Ecol Prog Ser 36:205-213

Craig JK, Rice JA, Crowder LB, Nadeau DA (2007) Densitydependent growth and mortality in an estuary-dependent fish: an experimental approach with juvenile spot Leiostomus xanthurus. Mar Ecol Prog Ser 343:251-262

> Cusson M, Bourget E (2005) Global patterns of macroinvertebrate production in marine benthic habitats. Mar Ecol Prog Ser 297:1-14

de Montaudouin X, Bachelet G (1996) Experimental evidence of complex interactions between biotic and abiotic factors in the dynamics of an intertidal population of the bivalve Cerastoderma edule. Oceanol Acta 19:449-463

de Vlas J (1985) Secondary production by siphon regeneration in a tidal flat population of Macoma balthica. Neth J Sea Res 19:147-164

> Dolbeth M, Lillebø AI, Cardoso PG, Ferreira SM, Pardal MA (2005) Annual production of estuarine fauna in different environmental conditions: an evaluation of the estimation methods. J Exp Mar Biol Ecol 326:115-127

Dolbeth M, Cusson M, Sousa R, Pardal MA (2012) Secondary production as a tool for better understanding of aquatic ecosystems. Can J Fish Aquat Sci 69:1230-1253

Eleftheriou A, McIntyre A (2005) Methods for the study of marine benthos, 3rd edn. Blackwell Science, Oxford

Elkaim B, Irlinger JP (1987) Contribution à l'étude de la dynamique des populations de Pectinaria koreni Malmgren (polychète) en baie de Seine orientale. J Exp Mar Biol Ecol 107:171-197

> Emlen JM (1966) The role of time and energy in food preference. Am Nat 100:611-617

> Floeter J, Temming A (2003) Explaining diet composition of North Sea cod (Gadus morhua): prey size preference vs. prey availability. Can J Fish Aquat Sci 60:140-150

Fulford RS, Peterson MS, Grammer PO (2011) An ecological model of the habitat mosaic in estuarine nursery areas: Part I-interaction of dispersal theory and habitat variability in describing juvenile fish distributions. Ecol Modell 222:3203-3215

> Gallardo VA (1965) Observations on the biting profiles of three $0.1 \mathrm{~m}^{2}$ bottom-samplers. Ophelia 2:319-322

> Gee JM, Warwick RM, Davey JT, George CL (1985) Field 
experiments on the role of epibenthic predators in determining prey densities in an estuarine mudflat. Estuar Coast Shelf Sci 21:429-448

Gibson R (1994) Impact of habitat quality and quantity on the recruitment of juvenile flatfishes. Neth J Sea Res 32: 191-206

Gibson RN, Pihl L, Burrows MT, Modin J, Wennhage H, Nickell LA (1998) Diel movements of juvenile plaice Pleuronectes platessa in relation to predators, competitors, food availability and abiotic factors on a microtidal nursery ground. Mar Ecol Prog Ser 165:145-159

Gillet P, Torresani S (2003) Structure of the population and secondary production of Hediste diversicolor (O.F. Müller, 1776), (Polychaeta, Nereidae) in the Loire estuary, Atlantic Coast, France. Estuar Coast Shelf Sci 56: 621-628

Gilliers C, Le Pape O, Desaunay Y, Bergeron JP (2006) Growth and condition of juvenile sole (Solea solea L.) as indicators of habitat quality in coastal and estuarine nurseries in the Bay of Biscay with a focus on sites exposed to the Erika oil spill. Sci Mar 70:183-192

> Grall J, Le Loc'h F, Guyonnet B, Riera P (2006) Community structure and food web based on stable isotopes (delta N15 and delta C-13) analysis of a north eastern Atlantic maerl bed. J Exp Mar Biol Ecol 338:1-15

Gray JS, Wu RS, Or YY (2002) Effects of hypoxia and organic enrichment on the coastal marine environment. Mar Ecol Prog Ser 238:249-279

Griffin R, Pearce B, Handy RD (2012) Dietary preference and feeding selectivity of common dragonet Callionymus lyra in U.K. J Fish Biol 81:1019-1031

Hall S, Raffaelli D, Basford D, Robertson M (1990) The importance of flatfish predation and disturbance on marine benthos. J Exp Mar Biol Ecol 136:65-76

> Hampel H, Cattrijsse A, Elliott M (2005) Feeding habits of young predatory fishes in marsh creeks situated along the salinity gradient of the Schelde estuary, Belgium and The Netherlands. Helgol Mar Res 59:151-162

Hily C (1976) Ecologie benthique des pertuis charentais. Thèse de doctorat de $3^{\text {ème }}$ cycle. Université de Bretagne Occidentale, Brest

> Hily C, Le Bris H (1984) Dynamics of an Abra-Alba population (bivalve Scrobiculariidae) in the Bay of Brest. Estuar Coast Shelf Sci 19:463-475

Hinz H, Kroencke I, Ehrich S (2005) The feeding strategy of dab Limanda limanda in the southern North Sea: linking stomach contents to prey availability in the environment. J Fish Biol 67:125-145

Hinz H, Prieto V, Kaiser MJ (2009) Trawl disturbance on benthic communities: chronic effects and experimental predictions. Ecol Appl 19:761-773

Hoar WS, Randall DJ, Brett JR (1979) Growth and bioenergetics. Academic Press, New York, NY

Huret M, Sourisseau M, Petitgas P, Struski C, Léger F, Lazure P (2013) A multi-decadal hindcast of a physicalbiogeochemical model and derived oceanographic indices in the Bay of Biscay. J Mar Syst 109-110:S77-S94

Ivlev VS (1961) Experimental ecology of the feeding of fishes. Yale University Press, New Haven, CT

Jaccard P (1901) Distribution de la flore alpine dans le bassin des Dranses et dans quelques régions voisines. Bull Soc Vaud Sci Nat 37:241-272

Klein G, Rachor E, Gerlach SA (1975) Dynamics and productivity of two populations of the benthic tube-dwelling amphipod Ampelisca brevicornis (Costa) in Helgoland
Bight. Ophelia 14:139-159

Kopp D, Le Bris H, Grimaud L, Nerot C, Brind'Amour A (2013) Spatial analysis of the trophic interactions between two juvenile fish species and their preys along a coastal-estuarine gradient. J Sea Res 81:40-48

Lai YT, Chen JH, Lee LL (2011) Prey selection of a shellinvading leech as predicted by optimal foraging theory with consumption success incorporated into estimation of prey profitability. Funct Ecol 25:147-157

> Laurent AG (1963) The lognormal distribution and the translation method: description and estimation problems. J Am Stat Assoc 58:231-235

Lê S, Josse J, Husson F (2008) FactoMineR: an R package for multivariate analysis. J Stat Softw 25:1-18

Le Bris H, Glemarec M (1995) Macrozoobenthic communities of an oxygen under-saturated coastal ecosystem: the Bay of Vilaine (southern Brittany). Oceanol Acta 18: 573-581

> Le Bris H, Glémarec M (1996) Marine and brackish ecosystems of South Brittany (Lorient and Vilaine bays) with particular reference to the effect of the turbidity maxima. Estuar Coast Shelf Sci 42:737-753

> Le Pape O, Bonhommeau S (2013) The food limitation hypothesis for juvenile marine fish. Fish Fish (in press), doi:10.1111/faf.12063

Le Pape O, Chauvet F, Desaunay Y, Guerault D (2003) Relationship between interannual variations of the river plume and the extent of nursery grounds for the common sole (Solea solea, L.) in Vilaine Bay. Effects on recruitment variability. J Sea Res 50:177-185

> Lie U, Pamatmat MM (1965) Digging characteristics and sampling efficiency of the $0.1 \mathrm{~m}^{2}$ van Veen grab. Limnol Oceanogr 10:379-384

Lincoln RJ (1979) British marine Amphipoda: Gammaridea. British Museum, London

MacArthur RH, Pianka ER (1966) On optimal use of a patchy environment. Am Nat 100:603-609

> Mantel N (1967) The detection of disease clustering and a generalized regression approach. Cancer Res 27: 209-220

MarLIN (Marine Life Information Network) (2006) BIOTIC Biological Traits Information Catalogue. Marine Biological Association of the United Kingdom, Plymouth. www.marlin.ac.uk/biotic

Menesguen A (1980) La macrofaune benthique de la baie de Concarneau: peuplements, dynamique de populations, predation exercée par les poisons. Thèse de doctorat de $3^{\text {ème }}$ cycle. Université de Bretagne Occidentale, Brest

Nash RDM, Geffen AJ (2000) The influence of nursery ground processes in the determination of year-class strength in juvenile plaice Pleuronectes platessa L. in Port Erin Bay, Irish Sea. J Sea Res 44:101-110

> Nash RDM, Geffen AJ, Burrows MT, Gibson RN (2007) Dynamics of shallow-water juvenile flatfish nursery grounds: application of the self-thinning rule. Mar Ecol Prog Ser 344:231-244

> Nicolaidou A (1983) Life history and productivity of Pectinaria koreni Malmgren (Polychaeta). Estuar Coast Shelf Sci 17:31-43

> Nicolas D, Le Loc'h F, Desaunay Y, Hamon D, Blanchet A, Le Pape O (2007) Relationships between benthic macrofauna and habitat suitability for juvenile common sole (Solea solea, L.) in the Vilaine estuary (Bay of Biscay, France) nursery ground. Estuar Coast Shelf Sci 73: $639-650$ 
Peterson $\mathrm{CH}$, Summerson HC, Thomson E, Lenihan HS and others (2000) Synthesis of linkages between benthic and fish communities as a key to protecting essential fish habitat. Bull Mar Sci 66:759-774

Pihl L (1985) Food selection and consumption of mobile epibenthic fauna in shallow marine areas. Mar Ecol Prog Ser 22:169-179

Pinheiro J, Bates D, DebRoy S, Sarkar D, R Development Core Team (2013) nlme: linear and nonlinear mixed effects models. R Foundation for Statistical Computing, Vienna. http://cran.r-project.org/web/package/nlme/index. html

Posey MH, Alphin TD, Cahoon LB, Lindquist DG, Mallin MA, Nevers MB (2002) Top-down versus bottom-up limitation in benthic infaunal communities: direct and indirect effects. Estuaries 25:999-1014

R Development Core Team (2012) R: a language and environment for statistical computing. R Foundation for Statistical Computing, Vienna. www.r-project.org

> Rigolet C, Dubois SF, Thiébaut E (2014) Benthic control freaks: effects of the tubiculous amphipod Haploops nirae on the specific diversity and functional structure of benthic communities. J Sea Res 85:413-427

Ross SW (2003) The relative value of different estuarine nursery areas in North Carolina for transient juvenile marine fishes. Fish Bull 101:384-404

Shaw M, Jenkins GP (1992) Spatial variation in feeding, prey distribution and food limitation of juvenile flounder Rhombosolea tapirina Günther. J Exp Mar Biol Ecol 165: $1-21$

Shorygin AA (1931) Foods, selective capacity, and food interrelationships of certain Gobiidae of the Caspian Sea. Zool Zhur 18:27-53

Sköld M, Loo LO, Rosenberg R (1994) Production, dynamics and demography of an Amphiura filiformis population.
Mar Ecol Prog Ser 103:81-90

Strauss RE (1982) Influence of replicated subsamples and subsample heterogeneity on the linear index of food selection. Trans Am Fish Soc 111:517-522

> van der Veer HW, Witte JIJ (1993) The 'maximum growth/ optimal food condition' hypothesis: a test for 0-group plaice Pleuronectes platessa in the Dutch Wadden Sea. Mar Ecol Prog Ser 101:81-90

van Veen J (1933) Onderzoek naar het zandtransport von rivieren. De Ingenieur 48B:151-159

Vinagre C, Cabral HN (2008) Prey consumption by the juvenile soles, Solea solea and Solea senegalensis, in the Tagus estuary, Portugal. Estuar Coast Shelf Sci 78:45-50

Vinagre C, França S, Cabral HN (2006) Diel and semi-lunar patterns in the use of an intertidal mudflat by juveniles of Senegal sole, Solea senegalensis. Estuar Coast Shelf Sci 69:246-254

> Visser AW, Fiksen O (2013) Optimal foraging in marine ecosystem models: selectivity, profitability and switching. Mar Ecol Prog Ser 473:91-101

Wainwright P, Richard B (1995) Predicting patterns of prey use from morphology of fishes. Environ Biol Fishes 44: 97-113

Walters C, Christensen V, Pauly D (1997) Structuring dynamic models of exploited ecosystems from trophic mass-balance assessments. Rev Fish Biol Fish 7:139-172

Ward JH (1963) Hierarchical grouping to optimize an objective function. J Am Stat Assoc 58:236-244

- Werner EE, Mittelbach GG, Hall DJ, Gilliam JF (1983) Experimental tests of optimal habitat use in fish: the role of relative habitat profitability. Ecology 64:1525-1539

WoRMS Editorial Board (2013) World Register of Marine Species. www.marinespecies.org

Wouters N, Cabral HN (2009) Are flatfish nursery grounds richer in benthic prey? Estuar Coast Shelf Sci 83:613-620 
Appendix. ABEC values for all prey taxa in the Bay of Vilaine. These values are estimates and include uncertainties that are not quantified

\begin{tabular}{|c|c|c|c|}
\hline Taxa & $\begin{array}{c}\mathrm{ABEC} \\
\left(\mathrm{kJ} \mathrm{g}^{-1} \mathrm{yr}^{-1}\right)\end{array}$ & Taxa & $\begin{array}{c}\text { ABEC } \\
\left.\mathrm{kJ} \mathrm{g}^{-1} \mathrm{yr}^{-1}\right)\end{array}$ \\
\hline Abludomelita obtusata & 30.96 & Leptopentacta elongata & 0.13 \\
\hline Abra alba & 0.35 & Liocarcinus holsatus & 2.66 \\
\hline Abra nitida & 0.34 & Liocarcinus navigator & 3.96 \\
\hline Acanthocardia echinata & 2.25 & Liocarcinus pusillus & 8.06 \\
\hline Acrocnida brachiata & 0.14 & Lumbrineris gracilis & 1.65 \\
\hline Ampelisca spp. & 1.87 & Lumbrineris latreilli & 1.27 \\
\hline Ampelisca spinimana & 2.00 & Macoma balthica & 0.27 \\
\hline Ampelisca spinipes & 1.09 & Mactra stultorum & 0.44 \\
\hline Ampharete acutifrons & 1.49 & Magelona alleni & 1.05 \\
\hline Amphiura filiformis & 0.24 & Maldane glebifex & 0.70 \\
\hline Aphrodita aculeata & 0.53 & Melinna palmata & 1.51 \\
\hline Apseudopsis latreillii & 24.40 & Mytilus edulis & 5.32 \\
\hline Asthenognathus atlanticus & 0.88 & Nassarius reticulatus & 0.91 \\
\hline Bivalvia & 0.34 & Nemertea & 1.63 \\
\hline Bodotria scorpioides & 12.71 & Neoamphitrite edwardsi & 0.49 \\
\hline Brachyura & 16.90 & Nephtys cirrosa & 0.89 \\
\hline Capitella capitata & 1.81 & Nephtys hombergii & 0.97 \\
\hline Capitellidae & 1.79 & Nephtys hystricis & 0.79 \\
\hline Capitomastus minima & 1.37 & Nereis zonata & 0.68 \\
\hline Caprella spp. & 20.26 & Notomastus latericeus & 0.44 \\
\hline Cerastoderma edule & 0.87 & Nucula nitidosa & 0.31 \\
\hline Cerebratulus spp. & 0.36 & Ophiura albida & 2.16 \\
\hline Chaetopterus variopedatus & 0.63 & Ophiura ophiura & 2.36 \\
\hline Chaetozone setosa & 1.58 & Orbinia cuvierii & 0.38 \\
\hline Corbula gibba & 0.25 & Owenia fusiformis & 1.16 \\
\hline Corophium volutator & 2.40 & Paguridae & 7.28 \\
\hline Cylichna cylindracea & 0.44 & Phascolion (Phascolion) strombus & IS $\quad 0.57$ \\
\hline Diastylis spp. & 12.58 & Phaxas pellucidus & 0.60 \\
\hline Diastylis bradyi & 10.18 & Pherusa monilifera & 0.88 \\
\hline Diastylis rathkei & 9.47 & Pherusa plumosa & 0.82 \\
\hline Diopatra neapolitana & 0.74 & Philine aperta & 2.26 \\
\hline Euclymene lumbricoides & 0.84 & Pholoe minuta & 1.25 \\
\hline Euclymene oerstedi & 0.83 & Photis longicaudata & 18.36 \\
\hline Gammaridae & 20.54 & Pisidia longicornis & 22.75 \\
\hline Gastropoda & 5.11 & Pista cristata & 1.02 \\
\hline Glycera spp. & 1.32 & Polititapes virgineus & 0.07 \\
\hline Glycera convoluta & 0.84 & Polychaeta & 1.12 \\
\hline Glycera unicornis & 0.62 & Scalibregma inflatum & 0.97 \\
\hline Gnathia maxillaris & 20.23 & Schistomeringos rudolphii & 2.28 \\
\hline Golfingia (Golfingia) elongata & 0.45 & Sipunculus (Sipunculus) nudus & 0.30 \\
\hline Haploops nirae & 1.15 & Spiochaetopterus costarum & 1.39 \\
\hline Heteromastus filiformis & 1.33 & Spiophanes bombyx & 1.86 \\
\hline Inachus dorsettensis & 10.58 & Spisula subtruncata & 0.55 \\
\hline Kurtiella bidentata & 0.57 & Sternaspis scutata & 0.66 \\
\hline Labidoplax digitata & 0.17 & Terebellides stroemii & 0.99 \\
\hline Labioleanira yhleni & 0.51 & Thyasira flexuosa & 0.54 \\
\hline Lagis koreni & 0.46 & Turritella communis & 0.16 \\
\hline Lanice conchilega & 0.98 & & \\
\hline
\end{tabular}

Editorial responsibility: Christine Paetzold, Oldendorf/Luhe, Germany
Submitted: January 8, 2014; Accepted: November 12, 2014 Proofs received from author(s): February 18, 2015 